EXTENDED REPORT

\title{
The level of BLyS (BAFF) correlates with the titre of autoantibodies in human Sjögren's syndrome
}

\author{
X Mariette, S Roux, J Zhang, D Bengoufa, F Lavie, T Zhou, R Kimberly
}

Ann Rheum Dis 2003;62:168-171

See end of article for authors' affiliations

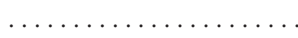

Correspondence to: Professor X Mariette Service de Rhumatologie, Hôpital de Bicêtre, 78 rue du Général Leclerc, 94275 Le Kremlin, Bicêtre CEDEX, France;

xavier.mariette@

bct.ap-hop-paris.fr

Accepted 21 June 2002

\begin{abstract}
Background: Increased levels of B lymphocyte stimulator (BLyS) have been detected in serum from patients with systemic lupus erythematosus and rheumatoid arthritis.

Objective: To determine the level of BLyS in serum from patients with primary's Siögren's syndrome (SS), another autoimmune disease in which B cell activation is high.

Methods: Serum samples from 49 patients with primary SS according to the revised European criteria were assayed for BLyS, quantitative immunoglobulins, and autoantibody levels and compared with samples from 47 healthy control subjects.

Results: The median level of BLyS was $5.99 \mathrm{ng} / \mathrm{ml}$ (25th-75th centile range $3.20-8.93 \mathrm{ng} / \mathrm{ml}$ ) in SS $v 2.49 \mathrm{ng} / \mathrm{ml}(25 \mathrm{th}-75 \mathrm{th}$ centile range $1.96-2.96 \mathrm{ng} / \mathrm{ml})$ in healthy controls $(\mathrm{p}<0.001)$. More importantly, among patients with SS, the presence of anti-SSA antibodies was associated with significantly higher levels of BLyS (medians $7.90 \mathrm{ng} / \mathrm{ml} v 3.70 \mathrm{ng} / \mathrm{ml} ; \mathrm{p}=0.008$ ) as was the presence of anti-SSB antibodies (medians $7.14 \mathrm{ng} / \mathrm{ml} \vee 3.70 \mathrm{ng} / \mathrm{ml} ; \mathrm{p}=0.02$ ) and of rheumatoid factor (medians 7.70 $\mathrm{ng} / \mathrm{ml} \vee 3.80 \mathrm{ng} / \mathrm{ml} ; \mathrm{p}=0.016$ ). The level of BLyS in three patients with a monoclonal gammopathy was higher than in the other patients (medians $26.53 \mathrm{ng} / \mathrm{ml} v 5.92 \mathrm{ng} / \mathrm{ml} ; p=0.13$ ). Higher levels of $\mathrm{BLyS}$ were associated with higher levels of gammaglobulins and $\lg G$. There was a strong correlation between BLyS and rheumatoid factor level $(r=0.71, p<0.0001)$, anti-SSA lgG level $(r=0.32, p=0.02)$ and anti-SSA IgM level $(r=0.39, \mathrm{p}=0.006)$.

Conclusion: In human SS the level of BLyS correlates with the level of autoantibodies. Thus, BLyS may play a part in activating specific autoreactive B cells and modulating the level of production of autoantibodies which are the hallmark of the disease. These findings raise the possibility of a novel therapeutic approach in human SS.
\end{abstract}

A ctivation of autoreactive B cells is a common feature of various autoimmune diseases. Recent studies in animal models have emphasised the possible pathogenic role of B cells and autoantibodies in autoimmune diseases. ${ }^{1-3}$ The recent recognition of several members of the tumour necrosis factor (TNF) receptor superfamily, BCMA, TACI, and BAFF-R (BR3), on lymphocytes has provided important insight into $B$ cell growth and survival. ${ }^{4-8}$ B lymphocyte stimulator (BLyS) (also named BAFF or TALL-1) appears to have an important role in autoimmunity because BLyS transgenic mice develop proteinuria and lupus-like disease, ${ }^{910}$ and a raised level of BLyS has been found in MRL-lpr/lpr and NZB/W-Fl autoimmune mice. ${ }^{11}$

The first two studies exploring this system in human autoimmune diseases showed raised levels of BLyS in serum from patients with systemic lupus erythematosus (SLE) and rheumatoid arthritis (RA). ${ }^{12}{ }^{13}$ However, primary Sjögren's syndrome (SS) is the autoimmune disease within which abnormal B cell activity is the most predominant. Very recently, Groom et al demonstrated that with increasing age BLyS transgenic mice develop severe sialadenitis and decreased saliva production. Moreover, they found raised levels of circulating BLyS in serum of humans with SS. ${ }^{14}$ We have assessed BLyS levels in serum from patients with primary SS and shown a correlation between the level of BLyS and both the level of immunoglobulins and the titre of autoantibodies.

\section{SUBJECTS AND METHODS Subjects}

We studied consecutive patients seen during a six month period in the sicca syndrome and Sjögren's syndrome consultation unit of Bicêtre Hospital in France. Forty nine patients fulfilled the diagnosis of primary SS according to the revised European criteria (4/6 of the EU diagnostic criteria, including at least one of anti-SSA and/or SSB antibodies, or a positive labial gland biopsy with a focus score $\geqslant 1) .{ }^{15}{ }^{16}$ None of these patients fulfilled criteria for another connective tissue disease. Control subjects $(n=47)$ were healthy volunteer donors recruited from the blood bank at the University of Alabama at Birmingham.

\section{Serological studies}

After obtaining written informed consent, venous blood was collected by venepuncture. Total gammaglobulin level was determined by standard serum protein electrophoresis. IgG, IgA, and IgM levels were measured by nephelometry. Rheumatoid factor was also determined by nephelometry, while antinuclear antibodies were measured by indirect immunofluorescence. Anti-SSB antibodies were determined by antigen-specific enzyme linked immunosorbent assay (ELISA; ANA profile, Pharmacia-Upjohn, Freiburg, Germany). Anti-SSA IgG were determined by quantitative antigenspecific ELISA according to the manufacturer's instructions (VARELISA SSA/Ro, Pharmacia-Upjohn). The same ELISA immunoassay was used for detection and quantification of anti-SSA IgM using an antihuman IgM horseradish peroxidase (HRP) conjugate. Immunofixation was performed to detect a monoclonal component in serum immunoglobulins.

Abbreviations: BLyS, B lymphocyte stimulator; BSA, bovine serum albumin; ELISA, enzyme linked immunosorbent assay; HRP, horseradish peroxidase; PBS, phosphate buffered saline; RA, rheumatoid arthritis; SLE, systemic lupus erythematosus; SS, Siögren's syndrome; TNF, tumour necrosis factor 

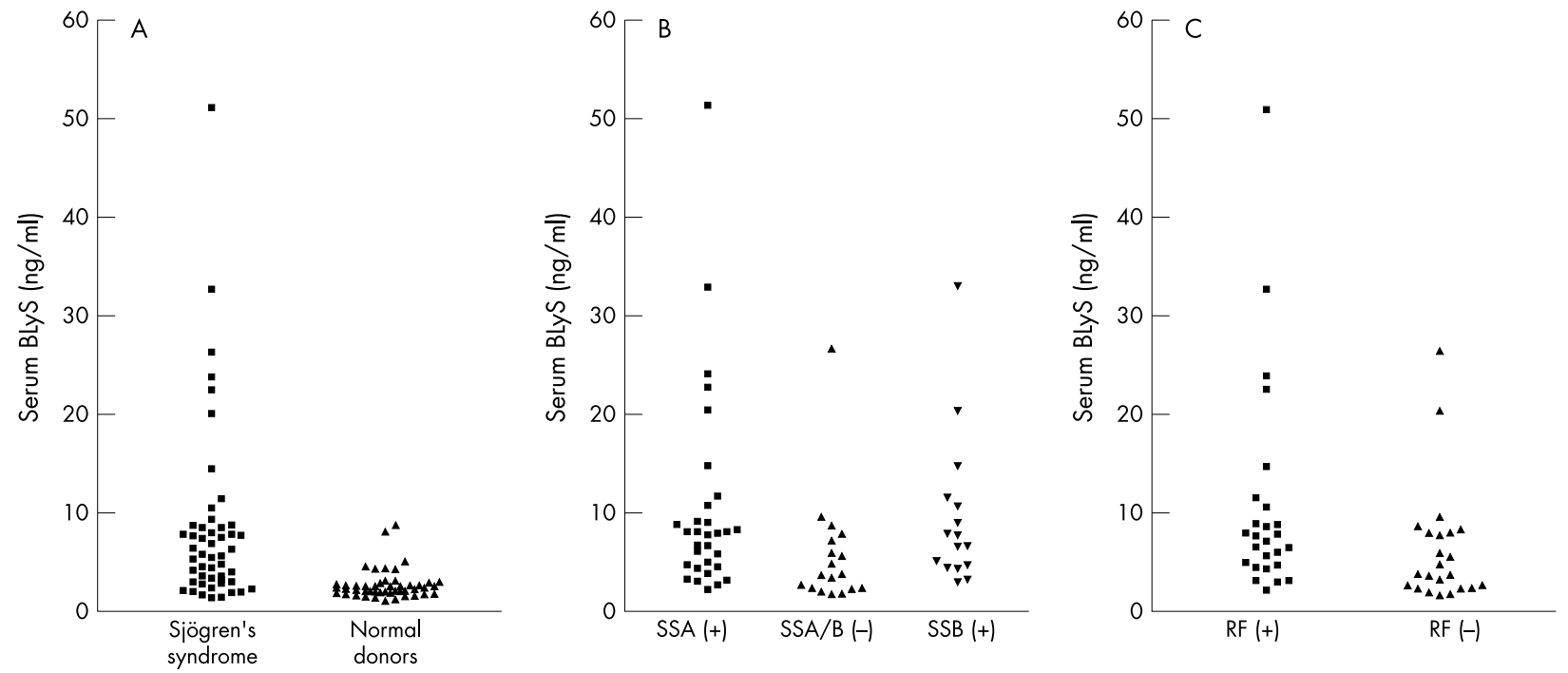

Figure 1 BLyS levels in patients with SS. (A) Serum levels of BLyS in the patients with SS $(n=49)$ were significantly higher than in normal donors $(n=47), p<0.001$. (B and C) Among patients with SS, BLyS levels were higher in patients with anti-SSA antibodies, anti-SSB antibodies, and in patients with RF ( $p=0.008, p=0.02$, and $p=0.016$, respectively; Mann-Whitney test). The medians of each group were: normal, 2.49 $\mathrm{ng} / \mathrm{ml} ; \mathrm{SS}, 5.99 \mathrm{ng} / \mathrm{ml} ; \mathrm{SS}$ with anti-SSA, $7.90 \mathrm{ng} / \mathrm{ml}$; SS with anti-SSB, $7.14 \mathrm{ng} / \mathrm{ml}$; SS without anti-SSA $/ \mathrm{SSB}, 3.70 \mathrm{ng} / \mathrm{ml} ; \mathrm{SS}$ with RF, 7.70 $\mathrm{ng} / \mathrm{ml}$; SS without RF, $3.80 \mathrm{ng} / \mathrm{ml}$.

A sandwich ELISA for measurement of the soluble form of $\mathrm{BLyS}^{\mathrm{TM}}$ was performed with modifications to previously described procedures. ${ }^{12}$ Briefly, 96 well plates were coated with purified murine anti-BLyS monoclonal antibody (clone 3D4, $\mathrm{mIgGl}$ ) at $2 \mu \mathrm{g} / \mathrm{ml}$ in phosphate buffered saline (PBS) at $4^{\circ} \mathrm{C}$ overnight and blocked with $1 \%$ bovine serum albumin (BSA)/ PBS. All specimens were diluted $1: 10$ in 3\% BSA/PBS and incubated in the ELISA plate at $37^{\circ} \mathrm{C}$ for four hours. After washing, the plate was incubated first with $0.2 \mu \mathrm{g} / \mathrm{ml}$ biotin conjugated polyclonal anti-BLyS antibody and then with 1:30 000 diluted HRP conjugated streptavidin (Southern Biotechnology, Birmingham, AL). To avoid any confounding effect of rheumatoid factor activity, an mIgGl isotype was used as a background control for the capture antibody with each specimen. The reaction was developed with trimethylbenzidine substrate (Sigma, St Louis, MO) and read in an E-Max plate reader (Molecular Devices, Sunnyvale, CA). In this assay, the absorbance values in the mIgGl control wells were subtracted from the corresponding anti-BLyS capture wells and were typically $<10 \%$ of total absorbance. There was no difference in values obtained with parallel serum and plasma samples. A standard curve using serial dilutions of recombinant BLyS was incorporated into each assay.

\section{Statistical analysis}

Statistical analysis were performed using Statview software (Abacus Concept Inc, Cary, NC, USA). Autoantibody, immunoglobulin, and BLyS levels were not normally distributed in patients with SS. Therefore, the non-parametric Mann-Whitney test was used to compare assay values in patients with those in controls. For correlations between the level of BLyS and the level of immunoglobulins and of autoantibodies, absolute values were log transformed to obtain a normal distribution and then Pearson's correlation coefficient was calculated. All tests of significance were two tailed.

\section{RESULTS}

Forty nine patients with clinical SS met the revised European criteria for the classification of SS. Among these patients antiSSA antibodies, anti-SSB antibodies, and rheumatoid factor were present in 31 (63\%), $16(33 \%)$, and $27(55 \%)$ of the group, respectively. Three patients had a serum monoclonal component without any clinical evidence of lymphoma.
The mean (SD) levels of total gammaglobulins and of the individual IgM, IgG, and IgA classes were 14.0 (9.2) g/l, 1.6 (1.7) g/l, 15.6 (8.9) g/l, and 3.2 (1.8) g/l, respectively. As shown
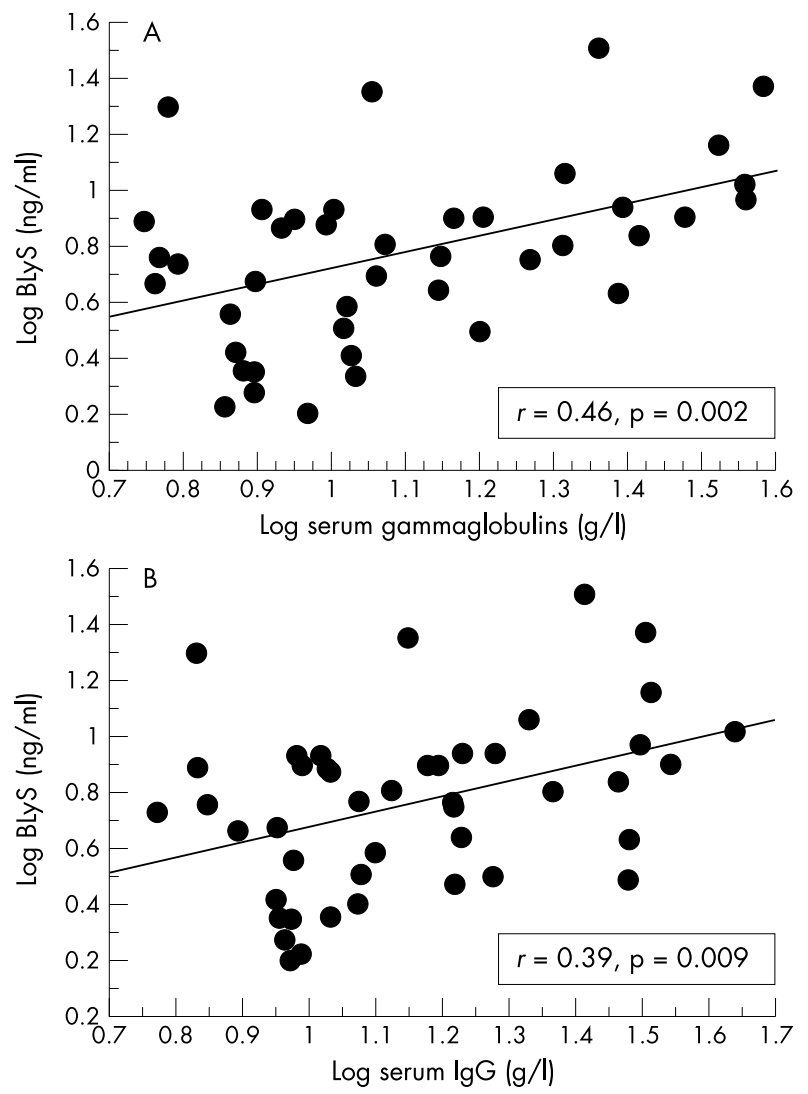

Figure 2 Correlation between BLyS and immunoglobulins. Correlations between serum levels of BLyS and serum gammaglobulin (A), and $\lg G(B)$ were determined for the 46 patients with SS without a monoclonal component. Analysis was based on $\log _{10}$ transformed values. The correlation coefficient was determined by the Pearson product statistic and the regression line is represented by the solid line. 

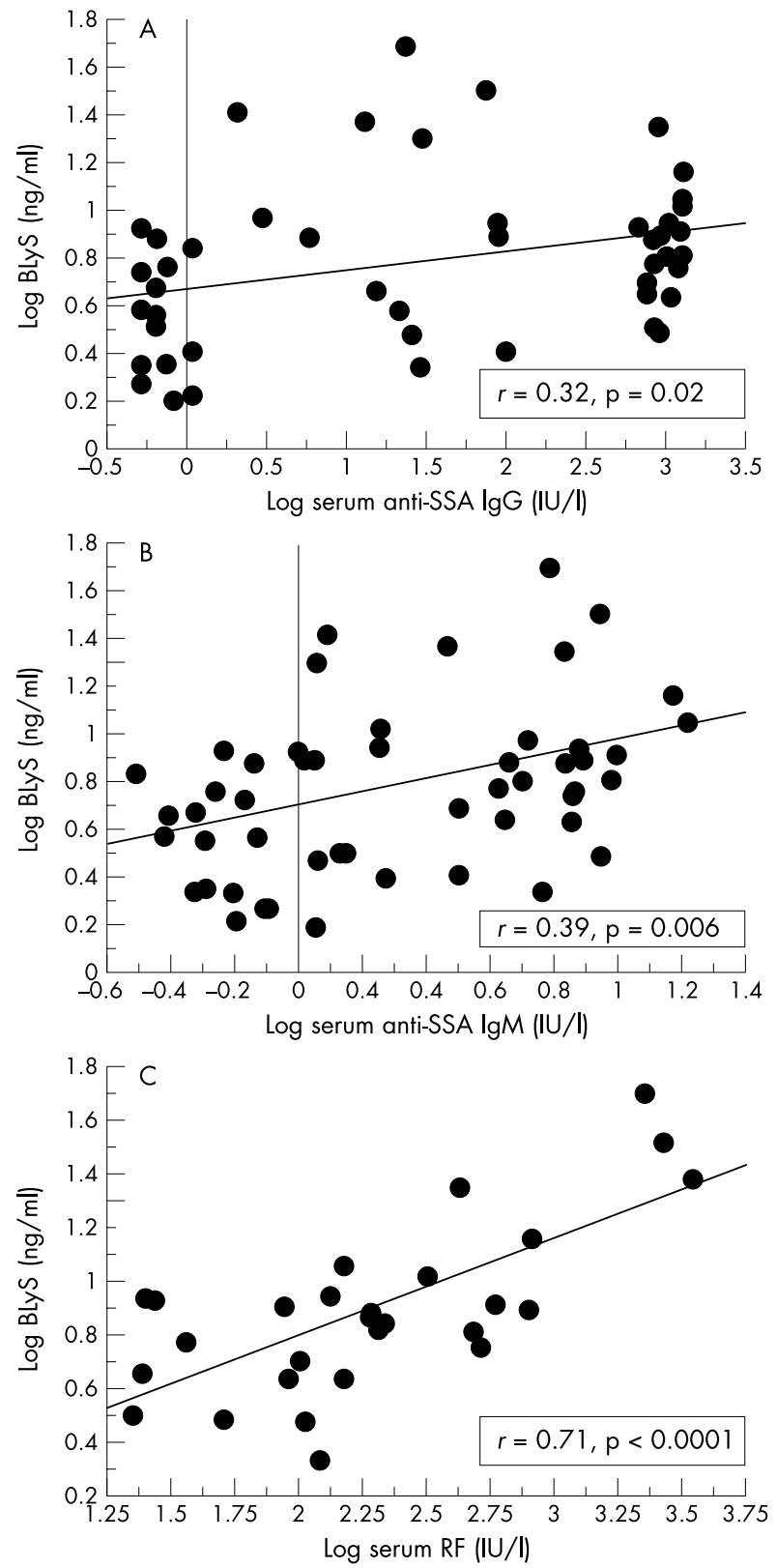

Figure 3 Correlation between BLyS and autoantibodies. Correlations between serum levels of BLyS and anti-SSA $\lg G(A)$, anti-SSA $\lg M(B)$ and serum RF $(C)$ were determined by $\log _{10}$ transformed values. The correlation coefficient was determined by the Pearson product statistic and the regression line is represented by the solid line.

in fig lA the median level of BLyS was $5.99 \mathrm{ng} / \mathrm{ml}$ (25th-75th centile range $3.20-8.93 \mathrm{ng} / \mathrm{ml}$ ) in SS compared with 2.49 $\mathrm{ng} / \mathrm{ml}$ (25th-75th centile range 1.96-2.96 ng/ml) in healthy controls $(\mathrm{p}<0.001)$. More importantly, among patients with SS, the presence of anti-SSA antibodies was associated with significantly higher levels of BLyS (medians $7.90 \mathrm{ng} / \mathrm{ml} v 3.70$ $\mathrm{ng} / \mathrm{ml} ; \mathrm{p}=0.008)$ as was the presence both of anti-SSB antibodies ( $7.14 \mathrm{ng} / \mathrm{ml} v 3.70 \mathrm{ng} / \mathrm{ml} ;(\mathrm{p}=0.02)$ (fig lB) and of rheumatoid factor $(7.70 \mathrm{ng} / \mathrm{ml} v 3.80 \mathrm{ng} / \mathrm{ml} ; \mathrm{p}=0.016)$ (fig 1C). The level of BLyS in the three patients with a monoclonal gammopathy was higher than in the other patients $(26.53$ $\mathrm{ng} / \mathrm{ml} v 5.92 \mathrm{ng} / \mathrm{ml} ; \mathrm{p}=0.13$ ).

Analysis of the 46 patients without a monoclonal gammopathy showed that higher levels of BLyS were associated with higher levels of gammaglobulins and IgG (fig 2). Interestingly, there was a strong correlation between BLyS and
anti-SSA IgG level $(r=0.32, \mathrm{p}=0.02)$, anti-SSA IgM level $(r=0.39, \mathrm{p}=0.006)$, and rheumatoid factor level $(r=0.71$, $\mathrm{p}<0.0001$ ) (fig 3).

\section{DISCUSSION}

We have shown that the BLyS level is raised in the serum of patients with SS and is at least as high as in patients with RA and SLE. As in the two latter diseases, but contrary to the findings of Groom et al, BLyS levels correlated with the presence of autoantibodies, including anti-SSA/SSB and rheumatoid factor. ${ }^{14}$ This observation parallels data in BLyS transgenic mice, in which increases of autoantibody titres are out of proportion to increases in total serum immunoglobulin levels. The level of BLyS in our study also correlated with the titre of anti-SSA antibodies and rheumatoid factor, suggesting a role, either primary or secondary, for BLyS in modulating the level of autoantibody production. The inability of Groom and colleagues to detect these relationships in their patient collection compared with our cohort is, perhaps, not surprising. Firstly, there is an apparent difference in the relative sensitivities of the BLyS ELISAs in the two studies. For example, using different capture and detection antibodies, Groom did not detect any significant differences in BLyS level between controls and patients with RA and SLE. Indeed, with the reagents in our assay, such a difference has been demonstrated in several independent cohorts. ${ }^{12}{ }^{13}$ Secondly, because only four patients with primary SS were Ro (SSA) negative, the power to detect differences in BLyS levels between Ro(SSA) positive and negative patients might have been insufficient.

In some autoimmune diseases, such as scleroderma and spondyloarthropathies, in which $\mathrm{B}$ cell activation is not predominant, raised levels of circulating BLyS have not been found.$^{13}$ Most likely, the primary location for the production and normal physiological action of BLyS is in local lymphoid and inflammatory microenvironments, analogous to TNF $\alpha$ and other immune system cytokines. It is striking, therefore, that when B cell activity is persistently abnormal, raised circulating BLyS levels are apparent. In mice transgenic for BLyS, there is an expansion of marginal zone B cells, ${ }^{9-11}$ which are also overexpressed in salivary glands of patients with SS. ${ }^{14}$ In primary SS, with its predominant $\mathrm{B}$ cell activation, this expansion of MZ B cells is particularly evident. Whether the corresponding increase in $\mathrm{B}$ cells frequently displaying a rheumatoid factor activity, ${ }^{17}$ in monoclonal gammopathies, and in lymphomas arising in salivary glands or in other mucosal associated lymphoid tissues is related to persistent and high levels of BLyS mediated B cell stimulation remains unclear. Answers to this question will require careful longitudinal studies of several different patient groups with and without these characteristics. Such studies might also include phenotyping of B cells for expression of the three BLyS receptors, BCMA, TACI and BAFF-R (BR3), because the net effect of BLyS on B cell biology might be dependent of the type of receptor expressed by the target $\mathrm{B}$ cells. ${ }^{8}$

In any case, it is clear from animal models that the ability to antagonise BLyS has a major impact on the manifestations of autoimmune disease. ${ }^{718}$ Analogous to anti-TNF strategies, which now have widespread application in the clinic, both monoclonal antibodies and receptor fusion proteins are effective in vitro. The success of fusion proteins in vivo in blocking BLyS and ameliorating several autoimmune disease models raises the possibility of a novel therapeutic approach in human SS and other diseases in which BLyS may participate in activating specific autoreactive B cells and modulating the level of production of autoantibodies, which are the hallmark of the disease. The prospect of a new therapeutic strategy with mechanistic specificity, without widespread side effects, and with application to the more common human autoimmune diseases is very promising. 


\section{ACKNOWLEDGEMENTS}

Grant support: Reagents provided by Human Genome Sciences, Inc.

BLyS $^{\mathrm{TM}}$ is a trademark of Human Genome Sciences, Inc.

\section{Authors' affiliations}

X Mariette, S Roux, F Lavie, Service de Rhumatologie, Hôpital de Bicêtre (Assistance publique-Hôpitaux de Paris (AP-HP)), Université Paris XI, INSERM EMI 0109, 94275 Le Kremlin Bicêtre, France

J Zhang, Human Genome Sciences, Rockville, MD, USA

D Bengoufa, Laboratoire d'Immunologie, Hôpital Saint-Louis (AP-HP), Université Paris VII, Paris, France

T Zhou, R Kimberly, Division of Clinical Immunology and Rheumatology, University of Alabama at Birmingham, Birmingham, AL, USA

\section{REFERENCES}

1 Korganow AS, Ji H, Mangialaio S, Duchatelle V, Pelanda R, Martin T, et al. From systemic $T$ cell self-reactivity to organ-specific autoimmune disease via immunoglobulins. Immunity 1999:10:451-61.

2 Matsumoto I, Staub A, Benoist C, Mathis D. Arthritis provoked by linked $T$ and $B$ cell recognition of a glycolytic enzyme. Science $1999 ; 286: 1732-5$

3 Schaller M, Burton DR, Ditzel HJ. Autoantibodies to GPI in rheumatoid arthritis: linkage between an animal model and human disease. Nat Immunol 2001;2:746-53.

4 Laabi Y, Gras MP, Carbonnel F, Brovet JC, Berger R, Larsen CJ, et al. A new gene, $B C M$, on chromosome 16 is fused to the interleukin 2 gene by a $t(4 ; 16)(q 26 ; p 13)$ translocation in a malignant $T$ cell lymphoma. EMBO J 1992; 11:3897-904.

5 Moore PA, Belvedere O, Orr A, Pieri K, LaFleur DW, Feng P, et al. BLyS: member of the tumor necrosis factor family and B lymphocyte stimulator. Science 1999;285:260-3

6 Shu HB, Hu WH, Johnson H. TALL-1 is a novel member of the TNF family that is down-regulated by mitogens. J Leukocyte Biol 1999;65:680.
7 Schneider P, MacKay F, Steiner V, Hofmann K, Bodmer IL, Holler N, et al. BAFF, a novel ligand of the tumor necrosis factor family, stimulates $B$ cell growth. J Exp Med 1999; 189:1747-56.

8 Thompson JS, Bixler SA, Qian F, Vora K, Scott ML, Cachero TG, et al. BAFF-R, a newly identified TNF receptor that specifically interacts with BAFF. Science 2001;293:2108-11.

9 Mackay F, Woodcock SA, Lawton P, Ambrose C, Baetsher M, Schneider $P$, et al. Mice transgenic for BAFF develop lymphocytic disorders along with autoimmune manifestations. J Exp Med 1999;190:1697-710.

10 Khare SD, Sarosi I, Xia X-Z, McCabe S, Miner K, Solovyev I, et al. Severe B cell hyperplasia and autoimmune disease in TALL-1 transgenic mice. Proc Natl Acad Sci USA 2000;97:3370-5.

11 Gross JA, Johnston J, Mudri S, Enselman R, Dillon SR, Madden K, et al. $\mathrm{TACl}$ and $\mathrm{BCMA}$ are receptors for a TNF homologue implicated in B-cell autoimmune disease. Nature 2000;404:995-9.

12 Zhang J, Roschke V, Baker KP, Wang Z, Alarcon GS, Fessler BJ, et al. Cutting edge: a role for $B$ lymphocyte stimulator in systemic lupus erythematosus. J Immunol 2001;166:6-10.

13 Cheema GS, Roschke V, Hilbert DM, Stohi W. Elevated serum B lymphocyte stimulator levels in patients with systemic immune-based rheumatic diseases. Arthritis Rheum 2001;44:1313-19.

14 Groom J, Kalled SL, Cutler AH, Olson C, Woodcock A, Schneider P, et al. Association of BAFF/BlyS overexpression with Sjögren's syndrome. J Clin Invest 2002; 109:59-68.

15 Vitali C, Bombardieri S. The European classification criteria for Siögren's syndrome (SS). Proposal for a modification of the rules for classification suggested by the analysis of the receiver operating characteristic (ROC) curve of the criteria performance [abstract]. J Rheumatol 1997;24:S50.

16 Vitali C, Bombardieri S, Jonsson R, Moutsopoulos HM, Alexander EL, Carsons SE, et al. Classification criteria for Siögren's syndrome: a revised version of the European criteria proposed by the American-European Consensus Group, Ann Rheum Dis 2002;61:554-8.

17 Mariette X. Lymphomas complicating Siögren's syndrome and hepatitis $C$ virus infection may share a common pathogenesis: chronic stimulation of rheumatoid factor B cells. Ann Rheum Dis 2001;60:1007-10.

18 Wang H, Marsters SA, Baker T, Chan B, Lec WP, Fu L, et al. TACl-ligand interactions are required for $T$ cell activation and collagen-induced arthritis in mice. Nat Immunol 2001;2:632-7. 